164

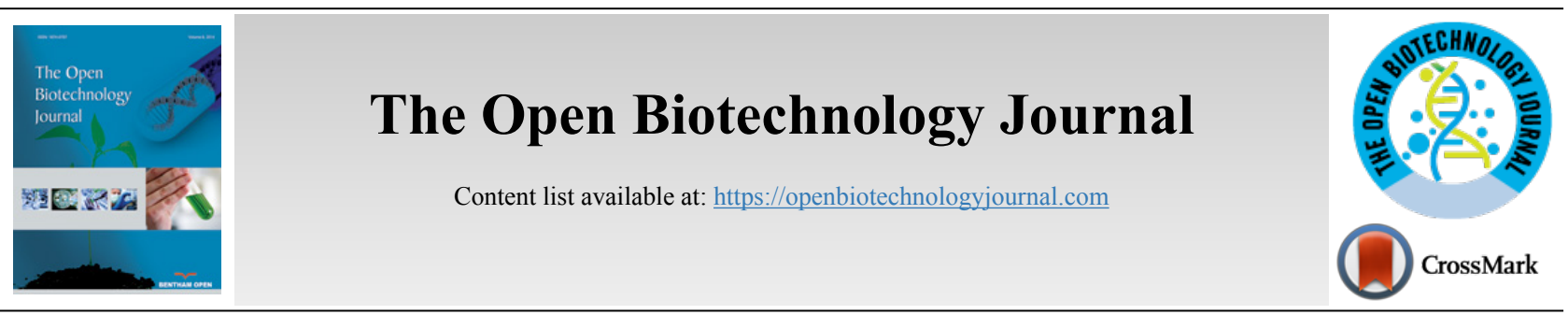

REVIEW ARTICLE

\title{
Polyphenols: A Comprehensive Review of their Nutritional Properties
}

\author{
Peyman Ebrahimi ${ }^{1}$ and Anna Lante ${ }^{2, *}$ \\ ${ }^{1}$ Department of Food Science and Technology, Ayatollah Amoli Branch, Islamic Azad University, Amol, Iran. \\ ${ }^{2}$ Department of Agronomy, Food, Natural Resources, Animals, and Environment-DAFNAE, Agripolis, University of Padova, 35020Legnaro, Italy.
}

\begin{abstract}
:
Polyphenols are the most prominent natural antioxidants found numerously in nature. They are secondary metabolites recognized for having high health benefits for consumers, even if the exploitation of these remarkable natural compounds is still a challenge. Moreover, there is a dilemma over the nutritional value of polyphenols. Hence, this paper seeks to review the classification, sources, anti-browning effect, antioxidant activity, nutritional property and anti-disease effect of polyphenols for better understanding the issues which need to be addressed in the valorization of
\end{abstract} these natural compounds.

Keywords: Phenolic compounds, Polyphenols, Antioxidants, Nutrition, Functional food, Glycation, Browning, Polyphenol oxidase.

\begin{tabular}{|l|l|l|l}
\hline Article History & Received: March 20, 2021 & Revised: June 22, 2021 & Accepted: July 12, 2021
\end{tabular}

\section{INTRODUCTION}

Phenolic compounds (polyphenols) are secondary metabolites synthetized in plants and possess one or more phenolic rings with (one or more) attached hydroxyl groups. Depending on the strength of phenolic rings, they are classified into several groups, including phenolic acids, flavonoids, stilbenes and lignans [1,2]. Polyphenols are naturally found in fruits [3, 4], vegetables [5], nuts [6], coffee [7], tea [8, 9], seeds and their agro-industrial by-products $[10,11]$.

Generally, more than half of the phenolic compounds have antibacterial, antifungal, anti-inflammatory and anti-tumor properties [12]. Even though these food components are not vital for the metabolism of the body, they improve the overall health of consumers by enhancing their physiological activity [2]. For this reason, studies on the secondary metabolites of plants have grown exponentially over the past years, and these compounds are considered potent substances for improving human health [13]. Furthermore, phenolic compounds act as natural antioxidants that enhance the nutritional value of food by retarding oxidative degradation of lipids. Therefore, adding phenolic compounds to food products extends their shelf life by increasing oxidative stability [14]. In this regard, antioxidants are well-known food additives included excessively in food products to maintain their initial quality [15]. Nevertheless, it is proved that synthetic antioxidants have

\footnotetext{
Address correspondence to this author at the Department of Agronomy, Food, Natural Resources, Animals, and Environment-DAFNAE, Agripolis, University of Padova, 35020 Legnaro, Italy; Tel: +39 049 8272920;
}

E-mail: anna.lante@unipd.it several adverse effects on consumers' healthiness due to their biological activities and their potential role in promoting serious diseases like cancer [16]. On the basis of these considerations, the employment of natural antioxidants as a substitute could be advantageous in reducing these drawbacks [17]. To date, numerous studies have identified phenolic compounds as nutritional sources with high health benefits used in manufacturing functional foods [18]. According to scientific literature, functional foods, compared to conventional foods, are defined as products with additional health benefits [19]. Currently, the usage of food ingredients with the aim of increasing the nutritional value and quality of food products has become an intriguing method for attracting consumers' attention. Indeed, adding bioactive compounds to food improves both the nutritional value and antioxidant capacity of food products [20] and could establish a link between food and health [21].

Therefore, it is necessary to study phenolic compounds explicitly from the perspective of nutrition and food science for better understanding the issues which need to be addressed for opening a new window in the valorization of these natural compounds.

\section{CLASSIFICATION OF PHENOLIC COMPOUNDS}

Polyphenols commonly have a C6-C3-C6 skeleton and are over 8000 types of chemical compounds with diverse structures and properties. Based on these considerations, polyphenols are split into different categories. For instance, they could be divided into two main groups: flavonoid compounds and non- 
flavonoid compounds [22 - 24]. Furthermore, in another type of classification (Fig. 1), depending on the phenolic rings and constituent elements connecting rings, phenolic compounds are divided into several groups, including flavonoids, phenolic acids, stilbenes, and lignans [25].

Phenolic acids form a large group of phenolic compounds comprised of hydroxycinnamic and hydroxybenzoic. The position and number of hydroxyl groups on the aromatic ring and the separate carbon skeleton are the reasons for the division of phenolic acids into these two groups [26]. Hydroxybenzoic acids include gallic acid, protocatechuic acid, hydroxybenzoic acid or gallotannin and ellagitannin. Nevertheless, simple esters with hydroxycarboxylic acids or glucose are usually made by hydroxycinnamic acids. In general, hydroxycinnamic acids have conjugated forms, such as hydroxyl esters. The free form of phenolic acids is a product of plant extraction. There are two aromatic rings in the flavonoid structure connected by a heterocyclic ring that differs in the degree of oxidation. This heterocyclic ring gives rise to various subtypes of flavonoids [27]. Flavanols are comprised of catechin, epicatechin, gallocatechin and epigallocatechin.
Moreover, kaempferol and quercetin are among the most pervasive flavonols [28]. The chemical structure of stilbenes is based on the main structure of $\mathrm{C}_{6}-\mathrm{C}_{2}-\mathrm{C}_{6}$, which has two aromatic rings connected by an ethylene bridge. Resveratrol is the most known stilbene [29].

\section{SOURCES OF PHENOLIC COMPOUNDS}

Foods contain a complex mixture of phenolic compounds [30]. It is reported that fruits and beverages are their main sources. While legumes and vegetables are the other sources of phenolic compounds, they own a lower amount of them. Among all the antioxidants, phenolic compounds are the most abundant types existing in the human diet, and their daily intake is more than the others (up to $1 \mathrm{~g}$ ) [14]. Many factors affect the concentration of phenolic compounds. These factors usually include environmental factors, such as soil, sunlight, rainfall, various farming methods, plant varieties, tree fruiting, as well as biochemical factors, such as degree of ripening, storage and cooking methods [31]. Table 1 provides information about the Total Phenolic Content (TPC) in different food sources.

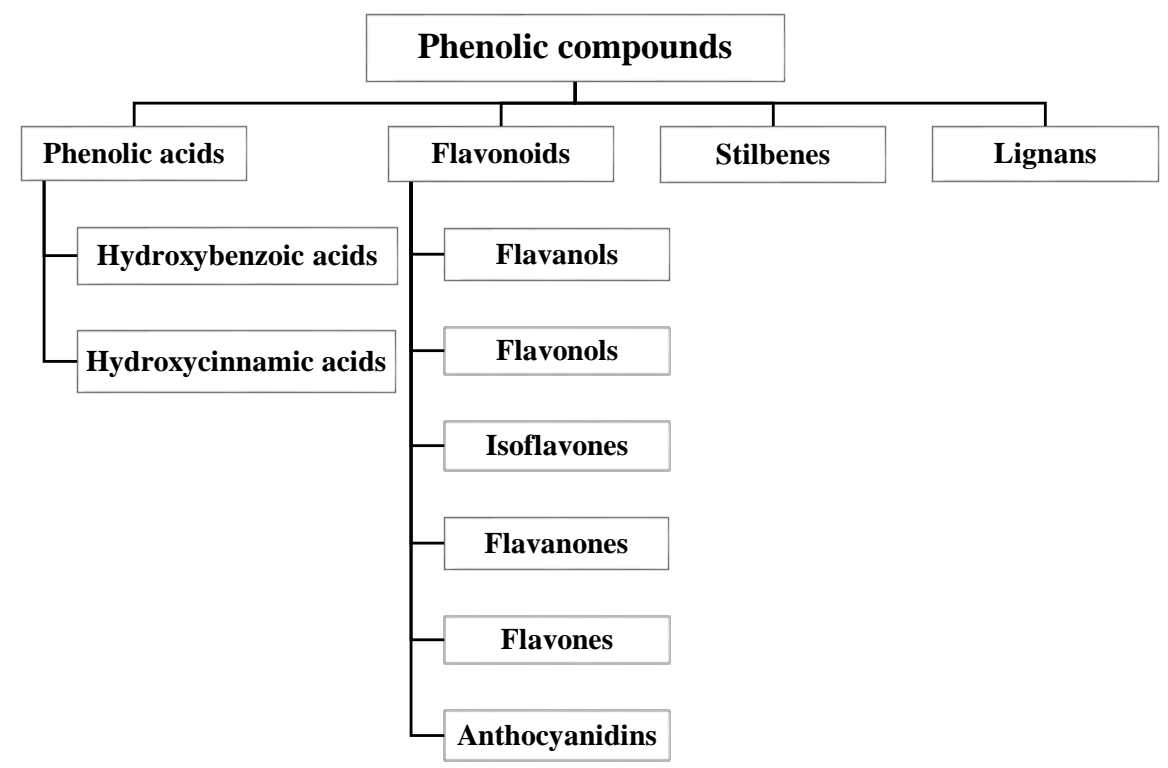

Fig. (1). Classification of phenolic compounds based on the phenolic rings and their connecting elements.

Table 1. TPC and predominant polyphenols in different food sources.

\begin{tabular}{|c|c|c|c|}
\hline Food Source & Predominant Polyphenols & $\begin{array}{c}\text { TPC (mg GAE /100 } \\
\text { g) }\end{array}$ & References \\
\hline Grape pomace powder & Epicatechin, catechin & $3886 \pm 522$ & {$[10]$} \\
\hline Plum fruit & $\begin{array}{l}\text { caffeoylquinic acids, feruloylquinic acid, p-coumaroylquinic acids, methyl } \\
\text { caffeoylquinates }\end{array}$ & $440 \pm 272$ & {$[32,33]$} \\
\hline Strawberry fruit & quercetin, kaempferol, cyanidin, pelargonidin, and ellagic acid & $238 \pm 86$ & {$[32,34]$} \\
\hline Mango fruit & chlorogenic, gallic, protocatechuic and vanillic acid & $60 \pm 26$ & {$[32,35]$} \\
\hline Pomegranate & $\begin{array}{l}\text { Epigallocatechin gallate, Epigallocatechin, Chlorogenic acid, } \rho \text { - } \\
\text { hydroxybenzoic acid }\end{array}$ & $\sim 145$ & [36] \\
\hline Doge rose & $\begin{array}{l}\text { Epigallocatechin, Chlorogenic acid, } \rho \text {-hydroxybenzoic acid, Epicatechin } \\
\text { gallate, Ellagic acid }\end{array}$ & $\sim 916$ & [36] \\
\hline
\end{tabular}




\begin{tabular}{|c|c|c|c|}
\hline Food Source & Predominant Polyphenols & $\begin{array}{c}\text { TPC (mg GAE /100 } \\
\text { g) }\end{array}$ & References \\
\hline Burdock root & chlorogenic acids, caffeic acid, quinic acid, caffeoylquinic acids & $1213 \pm 34$ & {$[37]$} \\
\hline $\begin{array}{l}\text { Ziziphus jujuba Mill. } \\
\text { (Rhamnaceae) fruits }\end{array}$ & Chlorogenic acid, Caffeic acid, Rosmarinic acid & $\sim 2100$ & {$[38]$} \\
\hline Apple & Procyanidin B2, Chlorogenic acid, (-)-Epicatechin & $1222 \pm 87$ & [39] \\
\hline Ginger powder & 6-gingerol & $4099 \pm 70$ & [40] \\
\hline Turmeric powder & Curcumin & $6676 \pm 100$ & [40] \\
\hline Green tea & Catechin & $\sim 140$ & [8] \\
\hline Apple powder & Chlorogenic acid & $\sim 435$ & [41] \\
\hline Non-alcoholic beer & Kaempferol, quercetin, tyrosol & $\sim 1017$ & {$[42,43]$} \\
\hline
\end{tabular}

\section{NUTRITIONAL PROPERTIES}

Generally, consumers need a wide variety of nutrients to have a standard health quality. A well-balanced diet should supply the essential nutrients for the diverse physiological groups of people. In order to give dietary recommendations and suggest a healthy intake, nutrient details are required [44]. Within a healthy eating plan, consumption of approximately $0.6 \mathrm{~g}$ of phenolic compounds per day is recommended [45]. According to scientific data, the average daily amount of phenolic compounds consumed by individuals is $\sim 1 \mathrm{~g}$ per person. Typically, personal taste and pattern of eating in various countries impact the consumption of foods containing phenolic compounds and their dietary intake [14].

The high nutritional value of phenolic compounds is a result of their antioxidant properties. In other words, the antioxidant activity of these compounds reduces the risk of chronic disorders, namely cancer and heart disorder. In addition to the benefits stemming from the antioxidant activity of phenolic compounds, their biological activity induces other advantageous mechanisms such as the prevention of noninfectious ailments (e.g. diabetes and obesity) [14]. Phenolic compounds also have protective effects against the invasion of pathogens and UV radiation [46]. For instance, Shiraz thyme (Zataria multiflora), owing to its phenolic compounds, has antimicrobial effects. Carvacrol, thymol, and eugenol are the main phenolic compounds of Shiraz thyme [47]. Based on the recent studies, the health-beneficial effects of phenolic compounds of natural foods are affected by environmental factors such as humidity and temperature of growing areas and culinary preparation techniques [48, 49]. In addition, these biologically active substances pass through the digestive tract, which affects the composition and content of phenolic substances, as reported in fruit juices by Mihailova et al. (2021) [50].

However, it should be considered that, in spite of the merits of polyphenols, they have some adverse effects at high concentrations. Indeed, polyphenols depending on their concentration, could be either antioxidant (in doses present in most foods) [51] or pro-oxidants (in pharmaceutical doses or in the presence of metal ions) [52]. Dietary supplements owning excessive concentrations of polyphenols are more responsible than polyphenol-rich foods for the adverse effects resulting from polyphenols in consumers. For instance, it has been reported that the excessive consumption of tea-based dietary supplements (approximately 10-29 mg per kg per day) causes liver injury (hepatotoxicity) [53 - 55]. In addition, caffeic acid at concentrations higher than $2 \%$ may raise the risk of iron deficiency in consumers and has undesirable interactions with synthetic medicines [56, 57]. Furthermore, high doses of ferulic acid cause some ailments such as headache, abortion, and hyperactivity in children [58].

\section{ANTIOXIDANT ACTIVITY}

It has been proven that antioxidants are one of the most important compounds suggested as a solution when it comes to food oxidation. These compounds are added to foods because of their ability to inhibit the activity of free radicals. Free radicals are known as carcinogenic compounds and cause many cardiovascular diseases [59]. Reactive Oxygen Species (ROS), including hydrogen peroxide, hydroxyl radicals and superoxide anions etc., are radicals that entail more than one unpaired electron in the outer orbit or highly reactive non-radicals. They may cause damage to the protective mechanisms of the cells and destroy the structure of DNA, proteins and lipids in biological systems [14]. The human body needs endogenous and exogenous antioxidants to minimize the effects of ROS. In this respect, phenolic compounds indicating antioxidant activity are highly crucial in human health [60].

The level of antioxidant activity of different phenolic compounds varies according to their chemical structure [61]. The antioxidant property of phenolic compounds stems from their hydroxyl groups and conjugated aromatic system, and it depends on the ability of phenolic compounds to give electrons to trap free radicals by forming stable phenoxyl compounds [62]. In general, the positive effect of phenolic cofactors increases the antioxidant capacity and performance in food products [63]. In cases where the concentration of phenolic compounds is high, due to the increase in the number of hydroxyl groups in the reaction medium and the probability of hydrogen donation to free radicals, the radical scavenging ability is noticeable [64]. The radical scavenging ability largely depends on the position and number of hydroxyl groups and the molecular weight of phenolic compounds. In phenolic compounds with lower molecular weight, hydroxyl groups are more readily available. Therefore, it should be noted that the type and quality of phenolic compounds are more responsible for the amount of antioxidant activity than their quantity [42]. 
Table 2. Anti-disease effects of different phenolic compounds or polyphenols-rich food sources.

\begin{tabular}{|c|c|c|c|}
\hline Disease & $\begin{array}{c}\text { Phenolic Compound / Polyphenols-Rich } \\
\text { Food Source Used as Remedy }\end{array}$ & Results & References \\
\hline Diabetes & $\begin{array}{c}\text { Extract of olive leaves (containing } \\
\text { oleuropein) }\end{array}$ & $\begin{array}{c}\text { Increase in antioxidant activity. Reduction in liver insulin receptor } \\
\text { substrate 1, insulin receptor A, HDL, superoxide dismutase, glutathione, } \\
\text { and catalase. }\end{array}$ & [81] \\
\hline Obesity & Curcumin & $\begin{array}{c}\text { Reduction in mean weight, body mass index (BMI), and waist } \\
\text { circumference }\end{array}$ & {$[82]$} \\
\hline Hyperlipidemia & Ferulic acid & Reduction of total cholesterol, LDL, triglyceride, and oxidative stress & {$[83]$} \\
\hline Hypertension & (-)-epicatechin & $\begin{array}{c}\text { Reduction of blood pressure and superoxide production in the aorta } \\
\text { persisted for two weeks after the treatment }\end{array}$ & {$[84]$} \\
\hline Atherosclerosis & $\begin{array}{c}\text { Yak-Kong soybean (containing coumestrol } \\
\text { and proanthocyanidins) }\end{array}$ & $\begin{array}{c}\text { Reduction in adhesion of THP-1 to LPS-stimulated human umbilical } \\
\text { vascular endothelial cells }\end{array}$ & {$[85]$} \\
\hline Thrombosis & $\begin{array}{c}\text { Blueberry extract (rich in different phenolic } \\
\text { compounds) }\end{array}$ & $\begin{array}{c}\text { Improvement in depressive symptoms and lipid profiles, and reduction in } \\
\text { gastrointestinal infection }\end{array}$ & {$[86]$} \\
\hline Inflammatory & $\begin{array}{c}\text { berries or fermented berries beverages } \\
\text { (containing high ellagic acid) }\end{array}$ & $\begin{array}{c}\text { Reduction in TNF- } \alpha \text {, IL-13, and iNOS expressions and modulation of the } \\
\text { levels of inflammatory markers. }\end{array}$ & {$[87]$} \\
\hline Alzheimer & Satureja cuneifolia plant (with high TPC) & $\begin{array}{c}\text { Increase in the inhabitation of acetylcholinesterase and } \\
\text { butyrylcholinesterase enzymes. }\end{array}$ & {$[88]$} \\
\hline
\end{tabular}

Phenolic compounds could contribute to the prevention of the oxidation process or biological oxidative damage. For instance, epicatechin has previously been identified as a substance reducing the rancidity of fish oil [65]. Grape pomace powder has high concentrations of phenolic compounds (especially epicatechin), and due to its high antioxidant activity, it can be used in delaying the oxidation of corn oil [10]. In addition, the use of dried grape pomace, which preserves its phenolic content and antioxidant activity for a long time, is convenient from the practical point of view within the functional foods industry as a nutraceutical or natural antioxidant ingredient [66].

Furthermore, 6-gingerol and curcumin were detected in the powders of ginger and turmeric rhizomes. Adding these powders to soybean oil improved its antioxidant activity and oxidative stability, resulting in health benefits to the consumers [67]. Moreover, Tinello and Lante (2020), in another study, proved that ginger and turmeric powders derived from freezedried rhizomes have a great antioxidant activity because of their high phenolic yields [40].

\section{ANTI-DISEASE EFFECT}

The imbalance between antioxidants and the concentrations of reactive oxygen species exposes the human body to oxidative stress, resulting in various disorders [68]. As shown in Table 2, natural phenolic compounds have beneficial effects on the prevention of many ailments, including obesity, diabetes, hypertension, hyperlipidemia, atherosclerosis, thrombosis and Alzheimer's. Consumption of foods containing a high concentration of phenolic compounds leads to the reduction of cardiovascular diseases [69]. These compounds, without having adverse effects, seem to be prominent for managing glucose intolerance and oxidative stress in diabetic people [70]. The higher intake of tea (black or green) than other polyphenol-rich foodstuffs lessens the risk of type 2 diabetes and stroke $[71,72]$. Luteolin and quercetin, which are two representatives of phenolic compounds, have an ameliorative impact on diabetes [73, 74]. Quercetin ceases the progress of hypertension caused by diabetes and improves the excessive contractile reactions of the aorta. There are many in vivo and in vitro studies proving the cardioprotective functions of quercetin [75]. Some of the phenolic compounds, such as ferulic acid, $\rho$-coumaric acid, $m$-coumaric acid and hydroxyhippuric acid, amplify the sensitivity of insulin and decline the rate, digestion, and absorption of sugar [76]. In addition, some commonly consumed phenolic compounds such as resveratrol, curcumin and catechins, particularly epigallocatechin gallates, originated from green tea, influence obesity and obesity-related inflammation [77].

It is reported that in people consuming high amounts of flavonoid-rich foods, the risk of stroke is little [78]. It has been suggested that the extract of Bael (Aegle marmelos) flower inhibits the oxidized LDL cholesterol, which raises the chance of heart attack or stroke [79]. Moreover, proanthocyanidins, as phenolic compounds mostly found in grape seeds, inhibit oxidized LDL cholesterol in human plasma. According to literature, these compounds protect the eye tissues from oxidative stress through improving antioxidant enzymes and diminishing prooxidant numbers. Thus, it could be claimed that proanthocyanidins act as a shield against eye disease [80 - 88].

\section{ANTI-BROWNING EFFECT}

Browning can be either enzymatic or non-enzymatic. There are plenty of anti-browning procedures, namely thermal processes, non-thermal technologies and the addition of synthetic additives like sulphites and organic acids [89, 90]. However, new anti-browning approaches consider replacing these traditional methods with adding natural compounds extracted from plants [36], agricultural by-products [91] and wastes $[39,40,92,93]$.

\subsection{Enzymatic Browning}

Generally, Polyphenol Oxidase (PPO) enzyme is the main responsible for the enzymatic browning. This enzyme is a copper-containing oxidoreductase catalyzing the oxidation of phenolic compounds and consequently leads to the deterioration of antioxidants and colour change of herbal 
foodstuffs during the processing [94]. Yuniarti et al. (2018) identified several phenolic inhibitors of PPO, including kaempferol, quercetin, and cyanidin in onion [95]. In addition, catechins, constituting a vast majority of TPC found in tea, act as a PPO competitive inhibitor because of their similarity to the substrate of PPO. Klimczak et al., (2017) reported that green tea extract inhibits the activity of PPO by an average of $75 \%$ in cloudy apple juice [96].

According to a research conducted by Zocca et al., (2011), dog rose fruit, known for its high quantity of ascorbic acid and phenolic compounds has anti-PPO activity due to its phydroxybenzoic acid content [36]. In another research, phenolic compounds altogether with high vitamin $\mathrm{C}$ content were found to be the reason for antioxidant properties in chili pepper, which inhibit the formation of undesired brown pigment [97]. Also, some of the phenolic compounds can act as a chelating agent [14].

\subsection{Non-Enzymatic Browning}

Non-enzymatic Maillard reaction is another type of browning. The occurrence of this reaction between the carbonyl groups of reducing sugars and free amino groups in lipids, proteins or nucleic acids ends up in the generation of an adduct named Advanced Glycation End-products (AGEs) [98]. Compared to other carbohydrates, fructose can readily form more intense fluorescent AGEs with basic amino acids [99]. The generation of AGEs results in the pathogenic mechanism of structural tissue damage, oxidative stress and inflammation, which arises debilitating diabetes, cataracts, atherosclerosis and Alzheimer [100 - 103]. Furthermore, the aggregation of this compound may give rise to Chronic Kidney Disease (CKD) [98]. AGE inhibitors are chelators and antioxidants at concentrations commonly found in food [104]. Phenolic compounds, due to their free radical scavenging activity, have a protective capability against the development of AGEs [98].

The buildup of AGEs readily occurs in the side chains of lysine, histidine and arginine on proteins. Since phenolic compounds are more reactive than these amino acids, they impede the development of AGEs by contesting with these amino acids. Glyoxal and methylglyoxal, as dicarbonyl compounds resulted from the second stage of Maillard reaction, are two main reactive precursors of AGEs in the human body. In some cases, phenolic compounds trap more methylglyoxal compared with aminoguanidine, which is a typical inhibition agent of glycation process. The reaction of the phenolic acid and glyoxal forms mono and di glyoxal adducts, which are the major mechanisms of preventing AGEs development. Indeed, the free radical scavenging ability of phenolic compounds is associated with their inhibitory effect on the development of AGEs. Furthermore, the phenolic compounds diminish the glyoxal level by inhibiting the oxidation of lipids [98].

So far, antiglycation activity has been reported for several phenolic compounds. For instance, Intagliata et al., (2021) successfully used esterified resveratrol with Trolox (a watersoluble analogue of vitamin E) to counteract free radicals, thus inhibiting the glycation process and also reducing oxidative mechanisms [105]. Błaszczak et al., (2020) studied the protective effects of the extracts of several species of tomato against AGEs. They concluded that the purified extracts of Black Prince tomatoes were the most potent inhibitors of AGEs. The inhibitory effect of the analyzed tomato fraction could be attributed to its rutin content, which is a phenolic compound [106]. Aailim et al., (2019) investigated the antiglycation effect of rice bran extract, which is a major source of phenolic compounds, including ferulic acid, $\rho$ coumaric acid, chlorogenic acid, syringic acid and caffeic acid. Their results proved that the formation of fructose-AGEs fluorescence was inhibited by the extract more effectively than aminoguanidine, which is a standard antiglycation agent. Ferulic acid and $\rho$-coumaric acid were the most dominant polyphenols in the extract. They showed an inhibitory effect on AGEs depending on their concentration [99]. The Rhizome of the Cimicifuga heracleifolia plant has an inhibitory effect on AGEs due to the presence of cinnamic acid and its by-products, such as ferulic acid and isoferulic acid [107]. Ferulic acid has antiglycation activity that mostly inhibits the advanced phase of glycation [108], and isoferulic acid prevents the development of fluorescent and non-fluorescent AGEs (CML) [109]. Caffeic acid and chlorogenic acid are potent glycation inhibitors [110]. According to recent studies, caffeic acid has more antiglycation activity than aminoguanidine [111]. Epicatechin, $\rho$-coumaric acid, and gallic acid decrease protein carbonyl, thiol oxidation and fluorescence AGEs development [112].

\section{IMPACT OF PROCESSING ON PHENOLIC CONTENT}

The bioavailability and bioactivity of phenolic compounds may be influenced by post-harvest and processing methods. In other words, unit operations and food processing methods could impact the TPC and individual phenolic compounds considerably. There are many factors influencing phenolic compounds during food processing, including temperature, pressure, etc. It is clear that the degradation of phenolic compounds in food products leads to a decrease in their nutritional value because the reduction of TPC gives rise to a reduction in antioxidant activity [87]. Since the major concentration of phenolic compounds usually exists in the outer parts of vegetables and fruits, the skinning/peeling process can considerably diminish the TPC. Moreover, the skinning/peeling process causes an increase in enzymatic browning by breaking the plant cell structure because the breakdown of cell structure boosts the interaction between PPO and phenolic compounds, which leads to colour change and deterioration of antioxidants $[90-93,113]$. The skin of potatoes contains approximately $190 \mathrm{mg}$ chlorogenic acid $/ \mathrm{kg}$. As a result of peeling, a noticeable amount of phenolic acids reduces in French fries [114].

The thermal process has a substantial effect on the content of phenolic compounds. The amount of the initial quercetin content in tomatoes and onions decreased by three-quarters after the boiling process and two-thirds after cooking in a microwave oven and less than a third after frying [114]. The epimerization of catechins present in green tea increases as a result of extraction using boiling or heating, and consequently, a lower amount of bioactive compounds remains in green tea 
[115]. Non-thermal processes also can affect the amount of phenolic compounds. For instance, cold plasma as a novel technology increased the TPC in blueberry juice. The reason for this is the breakdown of covalent bonds and cell membrane by chemically reactive species, charged particles, and UV photons created from Cold Plasma, which induces the release of phenolic compounds [116]. On the other hand, the degradation of PPO enzyme, which uses phenolic compounds as a substrate in enzymatic browning, could have a direct impact on maintaining phenolic compounds [117]. Overall, this is obvious that the concentration of phenolic compounds has a direct effect on its availability, antioxidant activity and nutritional value. Therefore, it is important to assess and compare the best processing conditions for maintaining the TPC and the antioxidant activity of food because the nutritional quality of food products diminishes by utilizing processes that decrease the content of phenolic compounds. In addition, it must be kept in mind that these biologically active substances pass through the digestive tract, which affects the composition and content of phenolic substances, and therefore their bioavailability [50].

\section{CONCLUSION}

Generally, phenolic compounds have remarkable nutritional properties due to their antiglycation capacity, antibrowning effect, and their crucial role in the prevention of diverse disorders, such as obesity, diabetes, hypertension, hyperlipidemia, atherosclerosis and cancer. In addition, these compounds have a noticeable amount of antioxidant activity, which is advantageous in food products for controlling lipid oxidation and increasing their health benefits. Therefore, owing to these extraordinary properties of phenolic compounds, the development of research in this field for evaluating the nutritional characteristics of these natural compounds not only can ensure the health of consumers to a certain extent but also can identify new sources of these compounds for the production of novel functional foods.

\section{LIST OF ABBREVIATIONS}

$$
\begin{array}{ll}
\text { ROS } & =\text { Reactive Oxygen Species } \\
\text { PPO } & =\text { Polyphenol Oxidase } \\
\text { AGEs } & =\text { Advance Glycation End Products } \\
\text { CKD } & =\text { Chronic Kidney Disease } \\
\text { TPC } & =\text { Total Phenolic Content }
\end{array}
$$

\section{CONSENT FOR PUBLICATION}

Not applicable.

\section{FUNDING}

This paper has not been supported or funded by an outside source.

\section{CONFLICT OF INTEREST}

The authors declare no conflict of interest, financial or otherwise.

\section{ACKNOWLEDGEMENTS}

Declared none.

\section{REFERENCES}

[1] Cutrim CS, Cortez MAS. A review on polyphenols: Classification, beneficial effects and their application in dairy products. Int J Dairy Technol 2018; 71(3): 564-78.

[http://dx.doi.org/10.1111/1471-0307.12515]

[2] Abbas M, Saeed F, Anjum FM, et al. Natural polyphenols: An overview. Int J Food Prop 2017; 20(8): 1689-99. [http://dx.doi.org/10.1080/10942912.2016.1220393]

[3] Mihaylova D, Popova A, Desseva I, et al. Comparative study of earlyand mid-ripening peach (Prunus persica L.) varieties: Biological activity, macro-, and micro- nutrient profile. Foods 2021; 10(1): 164. [http://dx.doi.org/10.3390/foods10010164] [PMID: 33466935]

[4] Gómez-Caravaca AM, Verardo V, Toselli M, Segura-Carretero A, Fernández-Gutiérrez A, Caboni MF. Determination of the major phenolic compounds in pomegranate juices by HPLC-DAD-ESI-MS. J Agric Food Chem 2013; 61(22): 5328-37.

[http://dx.doi.org/10.1021/jf400684n] [PMID: 23656584]

[5] Sarker U, Oba S. Salinity stress enhances color parameters, bioactive leaf pigments, vitamins, polyphenols, flavonoids and antioxidant activity in selected Amaranthus leafy vegetables. J Sci Food Agric 2019; 99(5): 2275-84

[http://dx.doi.org/10.1002/jsfa.9423] [PMID: 30324618]

[6] Herbello-Hermelo P, Lamas JP, Lores M, Domínguez-González R, Bermejo-Barrera P, Moreda-Piñeiro A. Polyphenol bioavailability in nuts and seeds by an in vitro dialyzability approach. Food Chem 2018; 254: $20-5$.

[http://dx.doi.org/10.1016/j.foodchem.2018.01.183]

[PMID: 29548442]

[7] Samsonowicz M, Regulska E, Karpowicz D, Leśniewska B Antioxidant properties of coffee substitutes rich in polyphenols and minerals. Food Chem 2019; 278: 101-9.

[http://dx.doi.org/10.1016/j.foodchem.2018.11.057] 30583350]

[8] Latifi Z, Biderooni BI, Ebrahimi P, Moghadam SK, Azadi R, Nasiraie LR. Effect of adding cinnamon and using spray drying method on antioxidant properties of instant green tea. Arch Pharm Pract (Mumbai) 2020; 1: 118.

[9] Cisneros-Yupanqui M, Lante A. Tea from the food science perspective: An overview. Open Biotechnol J 2020; 14(1): 78-83. [http://dx.doi.org/10.2174/1874070702014010078]

[10] Cisneros-Yupanqui M, Zagotto A, Alberton A, et al. Study of the phenolic profile of a grape pomace powder and its impact on delaying corn oil oxidation. Nat Prod Res 2020; 0(0): 1-5.

[http://dx.doi.org/10.1080/14786419.2020.1777414]

[PMID: 32552183]

[11] Akyol H, Riciputi Y, Capanoglu E, Caboni MF, Verardo V. Phenolic compounds in the potato and its byproducts: An overview. Int J Mol Sci 2016; 17(6): 835 .

[http://dx.doi.org/10.3390/ijms17060835] [PMID: 27240356]

[12] Rasouli H, Farzaei MH, Khodarahmi R. Polyphenols and their benefits: A review. Int J Food Prop 2017; 20(2): 1700-41. [http://dx.doi.org/10.1080/10942912.2017.1354017]

[13] Valdés L, Cuervo A, Salazar N, Ruas-Madiedo P, Gueimonde M, González S. The relationship between phenolic compounds from diet and microbiota: Impact on human health. Food Funct 2015; 6(8): 2424-39.

[http://dx.doi.org/10.1039/C5FO00322A] [PMID: 26068710]

[14] Cvejić JH, Krstonošić MA, Bursać M, Miljić U. Polyphenols.Nutraceutical and functional food components. Elsevier 2017; pp. 203-58.

[http://dx.doi.org/10.1016/B978-0-12-805257-0.00007-7]

[15] Cömert ED, Gökmen V. Evolution of food antioxidants as a core topic of food science for a century. Food Res Int 2018; 105: 76-93. [http://dx.doi.org/10.1016/j.foodres.2017.10.056] [PMID: 29433271]

[16] Gokoglu N. Novel natural food preservatives and applications in seafood preservation: A review. J Sci Food Agric 2019; 99(5): 2068-77.

[http://dx.doi.org/10.1002/jsfa.9416] [PMID: 30318589]

[17] Viana da Silva M, Santos MRC, Alves Silva IR, et al. Synthetic and natural antioxidants used in the oxidative stability of edible oils: An overview. Food Rev Int 2021; $\cdots:$ : 1-24.

[http://dx.doi.org/10.1080/87559129.2020.1869775] 
[18] Redan BW, Buhman KK, Novotny JA, Ferruzzi MG. Altered transport and metabolism of phenolic compounds in obesity and diabetes: Implications for functional food development and assessment. Adv Nutr 2016; 7(6): 1090-104.

[http://dx.doi.org/10.3945/an.116.013029] [PMID: 28140326]

[19] Lenssen KGM, Bast A, de Boer A. Clarifying the health claim assessment procedure of efsa will benefit functional food innovation. $\mathrm{J}$ Funct Foods 2018; 47: 386-96

[http://dx.doi.org/10.1016/j.jff.2018.05.047]

[20] Difonzo G, Squeo G, Pasqualone A, Summo C, Paradiso VM, Caponio F. The challenge of exploiting polyphenols from olive leaves: Addition to foods to improve their shelf-life and nutritional value. J Sci Food Agric 2020; 0-3

[http://dx.doi.org/10.1002/jsfa.10986] [PMID: 33275783]

[21] Pinent M, Blay M, Serrano J, Ardévol A. Effects of flavanols on the enteroendocrine system: Repercussions on food intake. Crit Rev Food Sci Nutr 2017; 57(2): 326-34.

[http://dx.doi.org/10.1080/10408398.2013.871221] [PMID: 26067747]

[22] Ola MS, Ahmed MM, Shams S, Al-Rejaie SS. Neuroprotective effects of quercetin in diabetic rat retina. Saudi J Biol Sci 2017; 24(6): 1186-94.

[http://dx.doi.org/10.1016/j.sjbs.2016.11.017] [PMID: 28855811]

[23] Teng H, Chen L. Polyphenols and bioavailability: An update. Crit Rev Food Sci Nutr 2019; 59(13): 2040-51.

[http://dx.doi.org/10.1080/10408398.2018.1437023] [PMID: 29405736]

[24] Cory H, Passarelli S, Szeto J, Tamez M, Mattei J. The role of polyphenols in human health and food systems: A mini-review. Front Nutr 2018; 5: 87.

[http://dx.doi.org/10.3389/fnut.2018.00087] [PMID: 30298133]

[25] Di Lorenzo C, Colombo F, Biella S, Stockley C, Restani P. Polyphenols and human health: the role of bioavailability. Nutrients 2021; 13(1): 1-30.

[http://dx.doi.org/10.3390/nu13010273] [PMID: 33477894]

[26] Laura A, Moreno-Escamilla JO, Rodrigo-García J, Alvarez-Parrilla E. Phenolic compounds.Postharvest physiology and biochemistry of fruits and vegetables. Elsevier 2019; pp. 253-71.

[27] Vuolo MM, Lima VS, Junior MRM. Phenolic compounds: Structure, classification, and antioxidant power.Bioactive compounds. Elsevier 2019; pp. 33-50.

[http://dx.doi.org/10.1016/B978-0-12-814774-0.00002-5]

[28] Tsimogiannis D, Oreopoulou V. Classification of phenolic compounds in plants.Polyphenols in plants. Elsevier 2019; pp. 263-84

[http://dx.doi.org/10.1016/B978-0-12-813768-0.00026-8]

[29] Neveu V, Perez-Jiménez J, Vos F, et al. Phenol-explorer: An online comprehensive database on polyphenol contents in foods. Database 2010.

[30] Martillanes S, Rocha-Pimienta J, Cabrera-Bañegil M, Martín-Vertedor D, Delgado-Adámez J. Application of phenolic compounds for food preservation: Food additive and active packaging phenolic compd Act. London: UK IntechOpen 2017; pp. 39-58.

[31] de Rezende WP, Borges LL, dos Santos DL, Alves NM, de Paula JR. Effect of environmental factors on phenolic compounds in leaves of syzygium jambos (L) Alston. Myrtaceae 2015.

[http://dx.doi.org/10.4172/2329-6798.1000157]

[32] Vasco C, Ruales J, Kamal-Eldin A. Total phenolic compounds and antioxidant capacities of major fruits from ecuador. Food Chem 2008; 111(4): 816-23.

[http://dx.doi.org/10.1016/j.foodchem.2008.04.054]

[33] Jaiswal R, Karaköse H, Rühmann S, et al. Identification of phenolic compounds in plum fruits (Prunus salicina L. and Prunus domestica L.) by high-performance liquid chromatography/tandem mass spectrometry and characterization of varieties by quantitative phenolic fingerprints. J Agric Food Chem 2013; 61(49): 12020-31. [http://dx.doi.org/10.1021/jf402288j] [PMID: 24152059]

[34] Aaby K, Ekeberg D, Skrede G. Characterization of phenolic compounds in strawberry (Fragaria $\mathrm{x}$ ananassa) fruits by different HPLC detectors and contribution of individual compounds to total antioxidant capacity. J Agric Food Chem 2007; 55(11): 4395-406. [http://dx.doi.org/10.1021/jf0702592] [PMID: 17472391]

[35] Palafox-Carlos H, Gil-Chávez J, Sotelo-Mundo RR, Namiesnik J, Gorinstein S, González-Aguilar GA. Antioxidant interactions between major phenolic compounds found in 'Ataulfo' mango pulp: Chlorogenic, gallic, protocatechuic and vanillic acids. Molecules 2012; 17(11): 12657-64.

[http://dx.doi.org/10.3390/molecules171112657] [PMID: 23103532]

[36] Zocca F, Lomolino G, Lante A. Dog rose and pomegranate extracts as agents to control enzymatic browning. Food Res Int 2011; 44(4): 957-63.

[http://dx.doi.org/10.1016/j.foodres.2011.02.010]

[37] Petkova N, Ivanov I, Mihaylova D, Lante A. Effect of pressure liquid extraction and ultrasonic irradiation frequency on inulin, phenolic content and antioxidant activity in burdock (Arctium Lappa 1.) roots. Acta Sci Pol Hortorum Cultus 2020; 19(3): 125-33.

[http://dx.doi.org/10.24326/asphc.2020.3.11]

[38] Trifonova D, Stoilova I, Marchev A, et al. Phytochemical constituents of pressurized liquid extract from ziziphus jujuba mill . ( Rhamnaceae ) fruits and in vitro inhibitory activity on $\alpha$-glucosidase. Pancreatic $\alpha$ Amylase and Lipase 2021; 27(2): 391-402.

[39] Tinello F, Mihaylova D, Lante A. Effect of dipping pre-treatment with unripe grape juice on dried "Golden Delicious" apple slices. Food Bioprocess Technol 2018; 11(12): 2275-85. [http://dx.doi.org/10.1007/s11947-018-2186-2]

[40] Tinello F, Lante A. Valorisation of ginger and turmeric peels as source of natural antioxidants. Plant Foods Hum Nutr 2019; 74(3): 443-5. [http://dx.doi.org/10.1007/s11130-019-00748-4] [PMID: 31183803]

[41] Roshani S, Shahidi SA, Ghorbani-Hasansaraei A, Raeisi N. Phytochemical content, physicochemical and microstructural properties of apple powder as affected by drying method. Lat Am Appl Res 2021; 51(1): 27-35.

[http://dx.doi.org/10.52292/j.laar.2021.205]

[42] Zabihpour T, Ebrahimi P, Kartalaee NM, et al. Determination of total phenolic and flavonoid contents, antioxidant activity and $\mathrm{b}$ vitamins of different iranian non-alcoholic beers. Int J Mod Agric 2021; 10(01): 308-18.

[43] Osorio-Paz I, Brunauer R, Alavez S. Beer and its non-alcoholic compounds in health and disease. Crit Rev Food Sci Nutr 2020; 60(20): 3492-505.

[http://dx.doi.org/10.1080/10408398.2019.1696278]

[PMID: 31782326

[44] Weichselbaum E, Hooper B, Buttriss J, et al. Behaviour change initiatives to promote a healthy diet and physical activity in e uropean countries. Nutr Bull 2013; 38(1): 85-99.

[http://dx.doi.org/10.1111/nbu.12011]

[45] Rabassa M, Cherubini A, Zamora-Ros R, et al. Low levels of a urinary biomarker of dietary polyphenol are associated with substantial cognitive decline over a 3-year period in older adults: The invecchiare in chianti study. J Am Geriatr Soc 2015; 63(5): 938-46. [http://dx.doi.org/10.1111/jgs.13379] [PMID: 25919574]

[46] Mihaylova D, Popova A, Alexieva I, Krastanov A, Lante A. Polyphenols as suitable control for obesity and diabetes. Open Biotechnol J 2018; 12(1): 219-28.

[http://dx.doi.org/10.2174/1874070701812010219]

[47] Boghori P, Latifi Z, Ebrahimi P, Mohamadi Kartalaei N, Dehghan L. Effect of whey protein concentrate-shiraz thyme (Zataria Multiflora) essential oil coating on the shelf life of peanut. J Adv Pharm Educ Res 2020; 10(S4): 131-8.

[48] Ma D, Li Y, Zhang J, et al. Accumulation of phenolic compounds and expression profiles of phenolic acid biosynthesis-related genes in developing grains of white, purple, and red wheat. Front Plant Sci 2016; 7: 528 .

[http://dx.doi.org/10.3389/fpls.2016.00528] [PMID: 27148345]

[49] Paznocht L, Kotíková Z, Burešová B, Lachman J, Martinek P. Phenolic acids in kernels of different coloured-grain wheat genotypes. Plant Soil Environ 2020; 66(2): 57-64.

[http://dx.doi.org/10.17221/380/2019-PSE]

[50] Mihaylova D, Desseva I, Stoyanova M, Petkova N, Terzyiska M, Lante A. Impact of In Vitro gastrointestinal digestion on the bioaccessibility of phytochemical compounds from eight fruit juices. Molecules 2021; 26(4): 1187.

[http://dx.doi.org/10.3390/molecules26041187] [PMID: 33672156]

[51] Xu D-P, Li Y, Meng X, et al. Natural antioxidants in foods and medicinal plants: Extraction, assessment and resources. Int J Mol Sci 2017; 18(1): 96.

[http://dx.doi.org/10.3390/ijms18010096] [PMID: 28067795]

[52] de Roos B, Duthie GG. Role of dietary pro-oxidants in the maintenance of health and resilience to oxidative stress. Mol Nutr Food Res 2015; 59(7): 1229-48.

[http://dx.doi.org/10.1002/mnfr.201400568] [PMID: 25546122]

[53] Navarro VJ, Khan I, Björnsson E, Seeff LB, Serrano J, Hoofnagle JH. Liver injury from herbal and dietary supplements. Hepatology 2017; 65(1): 363-73.

[http://dx.doi.org/10.1002/hep.28813] [PMID: 27677775]

[54] Bonkovsky HL. Hepatotoxicity associated with supplements 
containing Chinese green tea (Camellia sinensis). Ann Intern Med 2006; 144(1): 68-71.

[http://dx.doi.org/10.7326/0003-4819-144-1-200601030-00020] [PMID: 16389263]

[55] Chu KO, Wang CC, Chu CY, et al. Pharmacokinetic studies of green tea catechins in maternal plasma and fetuses in rats. J Pharm Sci 2006; 95(6): 1372-81.

[http://dx.doi.org/10.1002/jps.20594] [PMID: 16625654]

[56] Imam MU, Zhang S, Ma J, Wang H, Wang F. Antioxidants mediate both iron homeostasis and oxidative stress. Nutrients 2017; 9(7): 671. [http://dx.doi.org/10.3390/nu9070671] [PMID: 28657578]

[57] Gerber W, Steyn JD, Kotzé AF, Hamman JH. Beneficial pharmacokinetic drug interactions: A tool to improve the bioavailability of poorly permeable drugs. Pharmaceutics 2018; 10(3): 106.

[http://dx.doi.org/10.3390/pharmaceutics10030106]

[PMID: 30049988]

[58] Ebrahimi P, Shahidi S-A, Bijad M. A rapid voltammetric strategy for determination of ferulic acid using electrochemical nanostructure tool in food samples. J Food Meas Charact 2020; 1-8.

[59] Hayes JD, Dinkova-Kostova AT, Tew KD. Oxidative stress in cancer. Cancer Cell 2020; 38(2): 167-97.

[http://dx.doi.org/10.1016/j.ccell.2020.06.001] [PMID: 32649885]

[60] Bayir AG, Aksoy AN, Kocyigit A. The importance of polyphenols as functional food in health. Bezmialem Sci 2019; 7(2): 157.

[http://dx.doi.org/10.14235/bas.galenos.2018.2486]

[61] Anku W W, Mamo M A, Govender P P. Phenolic Compounds in water: Sources, reactivity, toxicity and treatment methods. Phenolic Compd sources, importance Appl 2017; 419-43.

[62] Reddy DNK, Huang F-Y, Wang S-P, Kumar R. Synergistic antioxidant and antibacterial activity of curcumin-c3 encapsulated chitosan nanoparticles. Curr Pharm Des 2020; 26(39): 5021-9. [http://dx.doi.org/10.2174/1381612826666200609164830] [PMID: 32516096]

[63] Cavalcanti RN, Santos DT, Meireles MAA. Non-thermal stabilization mechanisms of anthocyanins in model and food systems-An overview. Food Res Int 2011; 44(2): 499-509.

[http://dx.doi.org/10.1016/j.foodres.2010.12.007]

[64] Sánchez-Moreno C, Larrauri JA, Saura-Calixto F. Free radical scavenging capacity and inhibition of lipid oxidation of wines, grape juices and related polyphenolic constituents. Food Res Int 1999; 32(6): 407-12.

[http://dx.doi.org/10.1016/S0963-9969(99)00097-6]

[65] Yuan Y, Pan B, Niu X, et al. Impacts of epicatechin on the formation of advanced lipid oxidation end products (ALEs) in a fish oil oxidation model. Lebensm Wiss Technol 2019; 111: 582-7.

[http://dx.doi.org/10.1016/j.lwt.2019.05.081]

[66] Cisneros-Yupanqui M, Zagotto A, Alberton A, et al. Monitoring the antioxidant activity of an eco-friendly processed grape pomace along the storage. Nat Prod Res 2020; 0(0): 1-4.

[http://dx.doi.org/10.1080/14786419.2020.1815741] [PMID: 32878452]

[67] Tinello F, Lante A. Accelerated storage conditions effect on gingerand turmeric-enriched soybean oils with comparing a synthetic antioxidant BHT. Lebensm Wiss Technol 2020; 131109797 [http://dx.doi.org/10.1016/j.lwt.2020.109797]

[68] Hasbal G, Yilmaz-Ozden T, Can A. Antioxidant and antiacetylcholinesterase activities of Sorbus torminalis (L.) Crantz (wild service tree) fruits. J Food Drug Anal 2015; 23(1): 57-62. [http://dx.doi.org/10.1016/j.jfda.2014.06.006] [PMID: 28911446]

[69] Behl T, Bungau S, Kumar K, et al. Pleotropic effects of polyphenols in cardiovascular system. Biomed Pharmacother 2020; 130110714 [http://dx.doi.org/10.1016/j.biopha.2020.110714] [PMID: 34321158]

[70] Tanveer A, Akram K, Farooq U, Hayat Z, Shafi A. Management of diabetic complications through fruit flavonoids as a natural remedy. Crit Rev Food Sci Nutr 2017; 57(7): 1411-22.

[http://dx.doi.org/10.1080/10408398.2014.1000482] [PMID: 26065867]

[71] Lee PH, Nan H. Tea consumption and risk of type 2 diabetes: A longitudinal study with data from the chinese health and nutrition survey. Lancet Diabetes Endocrinol 2016; 4: S21 [http://dx.doi.org/10.1016/S2213-8587(16)30376-X]

[72] Arab L, Liu W, Elashoff D. Green and black tea consumption and risk of stroke: A meta-analysis. Stroke 2009; 40(5): 1786-92. [http://dx.doi.org/10.1161/STROKEAHA.108.538470] 19228856]

[73] Zhang M, He L, Liu J, Zhou L. Luteolin attenuates diabetic nephropathy through suppressing inflammatory response and oxidative stress by inhibiting STAT3 pathway. Exp Clin Endocrinol Diabetes 2020.

[http://dx.doi.org/10.1055/a-0998-7985] [PMID: 31896157]

[74] Bolouki A, Zal F, Bordbar H. Ameliorative effects of quercetin on folliculogenesis in diabetic mice: A stereological study. Gynecol Endocrinol 2020; 36(10): 864-8.

[http://dx.doi.org/10.1080/09513590.2019.1707796]

[PMID: 31889455]

[75] Mirsafaei L, Reiner Ž, Shafabakhsh R, Asemi Z. Molecular and biological functions of quercetin as a natural solution for cardiovascular disease prevention and treatment. Plant Foods Hum Nutr 2020; 75(3): 307-15.

[http://dx.doi.org/10.1007/s11130-020-00832-0] [PMID: 32588290]

[76] Paquette M, Medina Larqué AS, Weisnagel SJ, et al. Strawberry and cranberry polyphenols improve insulin sensitivity in insulin-resistant, non-diabetic adults: A parallel, double-blind, controlled and randomised clinical trial. Br J Nutr 2017; 117(4): 519-31. [http://dx.doi.org/10.1017/S0007114517000393] [PMID: 28290272]

[77] Wang S, Moustaid-Moussa N, Chen L, et al. Novel insights of dietary polyphenols and obesity. J Nutr Biochem 2014; 25(1): 1-18. [http://dx.doi.org/10.1016/j.jnutbio.2013.09.001] [PMID: 24314860]

[78] Gao Q, Dong J-Y, Cui R, et al. Consumption of flavonoid-rich fruits, flavonoids from fruits and stroke risk: A prospective cohort study. Br J Nutr $2021 ; \cdots: 1-8$.

[http://dx.doi.org/10.1017/S0007114521000404] [PMID: 33509322]

[79] Chandrasekara A, Daugelaite J, Shahidi F. DNA scission and LDL cholesterol oxidation inhibition and antioxidant activities of Bael (Aegle marmelos) flower extracts. J Tradit Complement Med 2018; 8(3): 428-35.

[http://dx.doi.org/10.1016/j.jtcme.2017.08.010] [PMID: 29992113]

[80] Unusan N. Proanthocyanidins in grape seeds: An updated review of their health benefits and potential uses in the food industry. J Funct Foods 2020; 67103861

[http://dx.doi.org/10.1016/j.jff.2020.103861]

[81] Al-Attar AM, Alsalmi FA. Effect of Olea europaea leaves extract on streptozotocin induced diabetes in male albino rats. Saudi J Biol Sci 2019; 26(1): 118-28.

[http://dx.doi.org/10.1016/j.sjbs.2017.03.002] [PMID: 30622415]

[82] Hodaei H, Adibian M, Nikpayam O, Hedayati M, Sohrab G. The effect of curcumin supplementation on anthropometric indices, insulin resistance and oxidative stress in patients with type 2 diabetes: A randomized, double-blind clinical trial. Diabetol Metab Syndr 2019; 11(1): 41 .

[http://dx.doi.org/10.1186/s13098-019-0437-7] [PMID: 31149032]

[83] Bumrungpert A, Lilitchan S, Tuntipopipat S, Tirawanchai N, Komindr S. Ferulic acid supplementation improves lipid profiles, oxidative stress, and inflammatory status in hyperlipidemic subjects: A randomized, double-blind, placebo-controlled clinical trial. Nutrients 2018; 10(6): 713.

[http://dx.doi.org/10.3390/nu10060713] [PMID: 29865227]

[84] Kluknavsky M, Balis P, Skratek M, Manka J, Bernatova I. (-)Epicatechin reduces the blood pressure of young borderline hypertensive rats during the post-treatment period. Antioxidants 2020; 9(2): 96.

[http://dx.doi.org/10.3390/antiox9020096] [PMID: 31979210]

[85] Lee CC, Dudonné S, Dubé P, et al. Comprehensive phenolic composition analysis and evaluation of Yak-Kong soybean (Glycine $\max )$ for the prevention of atherosclerosis. Food Chem 2017; 234: 486-93.

[http://dx.doi.org/10.1016/j.foodchem.2017.05.012]

[PMID: 28551265]

[86] Xu N, Meng $\mathrm{H}$, Liu $\mathrm{T}$, et al. Blueberry phenolics reduce gastrointestinal infection of patients with cerebral venous thrombosis by improving depressant-induced autoimmune disorder via mir-155mediated brain-derived neurotrophic factor. Front Pharmacol 2017; 8: 853.

[http://dx.doi.org/10.3389/fphar.2017.00853] [PMID: 29230173]

[87] Pap N, Fidelis M, Azevedo L. Berry polyphenols and human health: evidence of antioxidant, anti-inflammatory, microbiota modulation, and cell-protecting effects. Curr Opin Food Sci 2021.

[http://dx.doi.org/10.1016/j.cofs.2021.06.003]

[88] Taslimi P, Köksal E, Gören AC, et al. Anti-alzheimer, antidiabetic and antioxidant potential of satureja cuneifolia and analysis of its phenolic contents by LC-MS/MS. Arab J Chem 2020; 13(3): 4528-37. [http://dx.doi.org/10.1016/j.arabjc.2019.10.002]

[89] Lante A, Tinello F, Lomolino G. Effect of UV light on microbial 
proteases: from enzyme inactivation to antioxidant mitigation. Innov Food Sci Emerg Technol 2013; 17: 130-4.

[http://dx.doi.org/10.1016/j.ifset.2012.11.002]

[90] Lante A, Tinello F, Lomolino G. The use of polyphenol oxidase activity to identify a potential raisin variety. Food Biotechnol 2016; 30(2): 98-109.

[http://dx.doi.org/10.1080/08905436.2016.1166125]

[91] Lante A, Tinello F. Citrus hydrosols as useful by-products for tyrosinase inhibition. Innov Food Sci Emerg Technol 2015; 27: 154-9. [http://dx.doi.org/10.1016/j.ifset.2014.11.001]

[92] Tinello F, Lante A. Evaluation of antibrowning and antioxidant activities in unripe grapes recovered during bunch thinning. Aust $\mathbf{J}$ Grape Wine Res 2017; 23(1): 33-41.

[http://dx.doi.org/10.1111/ajgw.12256]

[93] Zocca F, Lomolino G, Lante A. Antibrowning potential of brassicacaea processing water. Bioresour Technol 2010; 101(10): $3791-5$.

[http://dx.doi.org/10.1016/j.biortech.2009.12.126] [PMID: 20116236]

[94] Tinello F, Lante A. Recent advances in controlling polyphenol oxidase activity of fruit and vegetable products. Innov Food Sci Emerg Technol 2018; 50: 73-83.

[http://dx.doi.org/10.1016/j.ifset.2018.10.008]

[95] Yuniarti T, Yuliana ND, Budijanto S. Inhibition of enzymatic browning by onion (Allium Cepa L.): Investigation on inhibitory mechanism and identification of active compounds. Curr Res Nutr Food Sci 2018; 6(3): 770.

[http://dx.doi.org/10.12944/CRNFSJ.6.3.19]

[96] Klimczak I, Gliszczyńska-Świgło A. Green tea extract as an antibrowning agent for cloudy apple juice. J Sci Food Agric 2017; 97(5): 1420-6.

[http://dx.doi.org/10.1002/jsfa.7880] [PMID: 27378649]

[97] Shaimaa GA, Mahmoud MS, Mohamed MR, Emam AA. Effect of heat treatment on phenolic and flavonoid compounds and antioxidant activities of some egyptian sweet and chilli pepper. Nat Prod Chem Res 2016.

[98] Khan M, Liu H, Wang J, Sun B. Inhibitory effect of phenolic compounds and plant extracts on the formation of advance glycation end products: A comprehensive review. Food Res Int 2020; 130(130)108933

[http://dx.doi.org/10.1016/j.foodres.2019.108933] [PMID: 32156381]

[99] Aalim H, Belwal T, Jiang L, Huang H, Meng X, Luo Z. Extraction optimization, antidiabetic and antiglycation potentials of aqueous glycerol extract from rice (Oryza Sativa L.) bran. Lebensm Wiss Technol 2019; 103: 147-54

[http://dx.doi.org/10.1016/j.lwt.2019.01.006]

[100] Chaudhuri J, Bains Y, Guha S, et al. The role of advanced glycation end products in aging and metabolic diseases: Bridging association and causality. Cell Metab 2018; 28(3): 337-52.

[http://dx.doi.org/10.1016/j.cmet.2018.08.014] [PMID: 30184484]

[101] Le Bagge S, Fotheringham AK, Leung SS, Forbes JM. Targeting the receptor for advanced glycation end products (RAGE) in type 1 diabetes. Med Res Rev 2020; 40(4): 1200-19.

[http://dx.doi.org/10.1002/med.21654] [PMID: 32112452]

[102] Sharma A, Weber D, Raupbach J, et al. Advanced glycation end products and protein carbonyl levels in plasma reveal sex-specific differences in parkinson's and alzheimer's disease. Redox Biol 2020; 34101546

[http://dx.doi.org/10.1016/j.redox.2020.101546] [PMID: 32460130]

[103] Fishman SL, Sonmez H, Basman C, Singh V, Poretsky L. The role of advanced glycation end-products in the development of coronary artery disease in patients with and without diabetes mellitus: A review. Mol Med 2018; 24(1): 59.

[http://dx.doi.org/10.1186/s10020-018-0060-3] [PMID: 30470170]

[104] Crascì L, Lauro MR, Puglisi G, Panico A. Natural antioxidant polyphenols on inflammation management: Anti-glycation activity vs metalloproteinases inhibition. Crit Rev Food Sci Nutr 2018; 58(6): 893-904.

[http://dx.doi.org/10.1080/10408398.2016.1229657]

[PMID: 27646710]

[105] Intagliata S, Spadaro A, Lorenti M, et al. In Vitro antioxidant and antiglycation activity of resveratrol and its novel triester with trolox. Antioxidants 2020; 10(1): 12

[http://dx.doi.org/10.3390/antiox10010012] [PMID: 33374280]

[106] Blaszczak W, Jeż M, Szwengiel A. Polyphenols and inhibitory effects of crude and purified extracts from tomato varieties on the formation of advanced glycation end products and the activity of angiotensinconverting and acetylcholinesterase enzymes. Food Chem 2020; 314126181

[http://dx.doi.org/10.1016/j.foodchem.2020.126181]

[PMID: 31954938]

[107] Sadowska-Bartosz I, Bartosz G. Prevention of protein glycation by natural compounds. Molecules 2015; 20(2): 3309-34.

[http://dx.doi.org/10.3390/molecules20023309] [PMID: 25690291]

[108] Silván JM, Assar SH, Srey C, Dolores Del Castillo M, Ames JM. Control of the maillard reaction by ferulic acid. Food Chem 2011; 128(1): 208-13.

[http://dx.doi.org/10.1016/j.foodchem.2011.03.047]

[PMID: 25214350]

[109] Meeprom A, Sompong W, Chan CB, Adisakwattana S. Isoferulic acid, a new anti-glycation agent, inhibits fructose- and glucose-mediated protein glycation in vitro. Molecules 2013; 18(6): 6439-54. [http://dx.doi.org/10.3390/molecules18066439] [PMID: 23722732]

[110] Gugliucci A, Bastos DHM, Schulze J, Souza MFF. Caffeic and chlorogenic acids in Ilex paraguariensis extracts are the main inhibitors of AGE generation by methylglyoxal in model proteins. Fitoterapia 2009; 80(6): 339-44.

[http://dx.doi.org/10.1016/j.fitote.2009.04.007] [PMID: 19409454]

[111] Bains Y, Gugliucci A. Ilex paraguariensis and its main component chlorogenic acid inhibit fructose formation of advanced glycation endproducts with amino acids at conditions compatible with those in the digestive system. Fitoterapia 2017; 117: 6-10.

[http://dx.doi.org/10.1016/j.fitote.2016.12.006] [PMID: 28012919]

[112] Ardestani A, Yazdanparast R. Cyperus rotundus suppresses AGE formation and protein oxidation in a model of fructose-mediated protein glycoxidation. Int J Biol Macromol 2007; 41(5): 572-8.

[http://dx.doi.org/10.1016/j.ijbiomac.2007.07.014] [PMID: 17765965]

[113] Lante A, Tinello F, Nicoletto M. UV-A light treatment for controlling enzymatic browning of fresh-cut fruits. Innov Food Sci Emerg Technol 2016; 34: 141-7.

[http://dx.doi.org/10.1016/j.ifset.2015.12.029]

[114] Clifford MN. Chlorogenic acids and other cinnamates-nature, occurrence, dietary burden, absorption and metabolism. J Sci Food Agric 2000; 80(7): 1033-43.

[http://dx.doi.org/10.1002/(SICI)1097-0010(20000515)80:7<1033::AI D-JSFA595>3.0.CO;2-T]

[115] Lante A, Friso D. Oxidative stability and rheological properties of nanoemulsions with ultrasonic extracted green tea infusion. Food Res Int 2013; 54(1): 269-76.

[http://dx.doi.org/10.1016/j.foodres.2013.07.009]

[116] Hou Y, Wang R, Gan Z, et al. Effect of cold plasma on blueberry juice quality. Food Chem 2019; 290: 79-86.

[http://dx.doi.org/10.1016/j.foodchem.2019.03.123] 31000059]

[117] Khani MR, Shokri B, Khajeh K. Studying the performance of dielectric barrier discharge and gliding arc plasma reactors in tomato peroxidase inactivation. J Food Eng 2017; 197: 107-12. [http://dx.doi.org/10.1016/j.jfoodeng.2016.11.012]

(C) 2021 Ebrahimi and Lante.

This is an open access article distributed under the terms of the Creative Commons Attribution 4.0 International Public License (CC-BY 4.0), a copy of which is available at: (https://creativecommons.org/licenses/by/4.0/legalcode). This license permits unrestricted use, distribution, and reproduction in any medium, provided the original author and source are credited. 